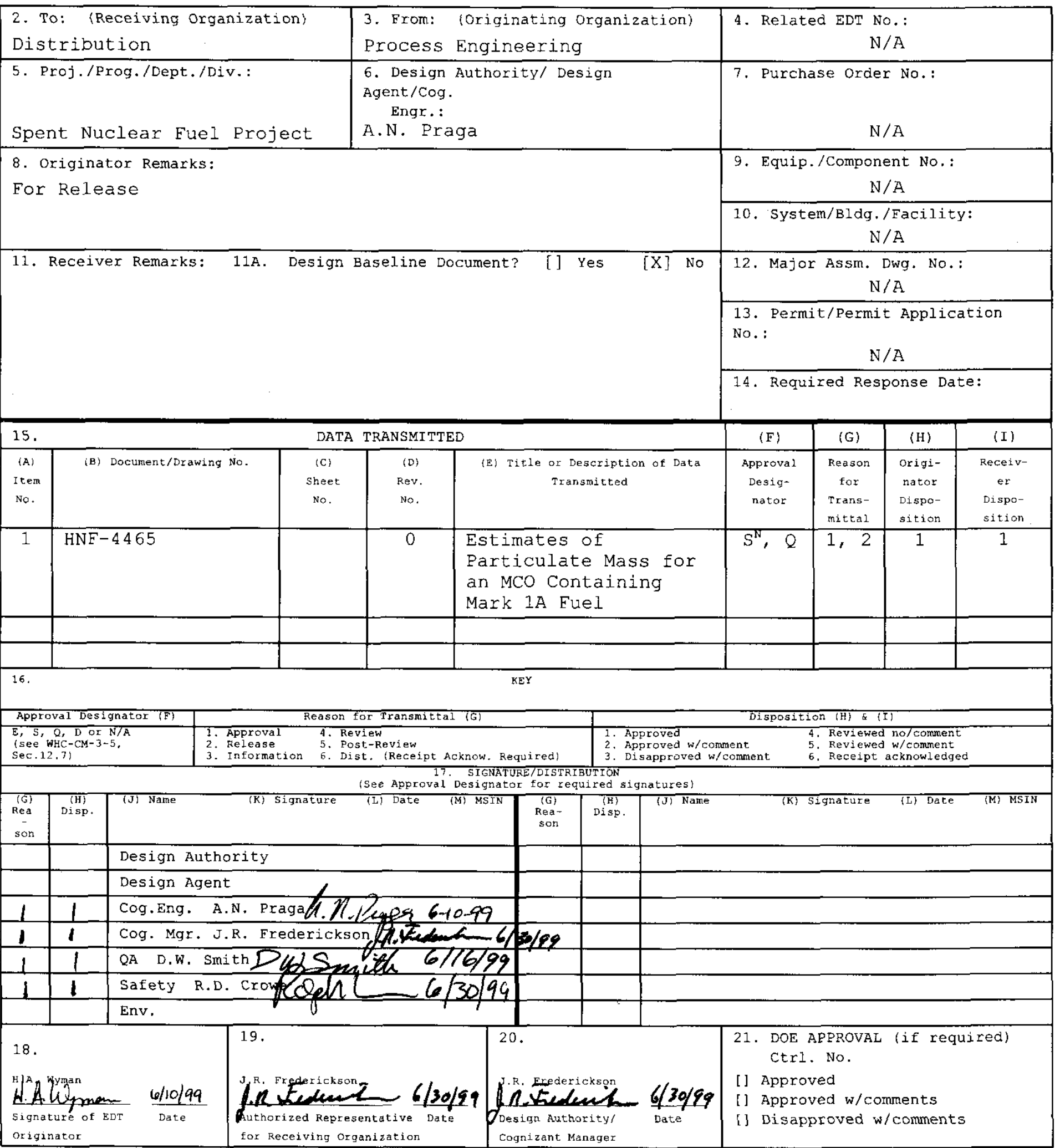

BD-7400-172-2 (05/96) GEF097 


\section{Estimates of Particulate Mass for an MCO Containing Mark 1A Fuel}

\section{H. A. Wyman}

COGEMA Engineering Corporation, Richland, WA 99352

U.S. Department of Energy Contract DE-AC06-96RL13200

EDT/ECN: 627104

UC: 510

Org Code: $2 \mathrm{~T} 350$

Charge Code: LB051

B\&R Code: EW7040000

Total Pages: 16

Key Words: Multi-Canister Overpack, MCO, Mark 1A, Particulate, Adhering, Particulate, Canister Particulate, Cladding Film(s), Oxide Film(s)

Abstract: High, best estimate, and low values are given for particulate inventories within an MCO basket containing freshly cleaned Mark $1 \mathrm{~A}$ fuel. The findings are compared with the estimates of particulate inventories for an MCO basket containing freshly cleaned Mark IV fuel.

TRADEMARK DISCLAIMER. Reference herein to any specific commercial product, process, or service by trade name, trademark, manufacturer, or otherwise, does not necessarily constitute or imply its endorsement, recommendation, or favoring by the United States Government or any agency thereof or its contractors or subcontractors.

Printed in the United States of America. To obtain copies of this document, contact: Document Control Services, P.O. Box 950, Mailstop H6-08, Richland WA 99352, Phone (509) 372-2420; F
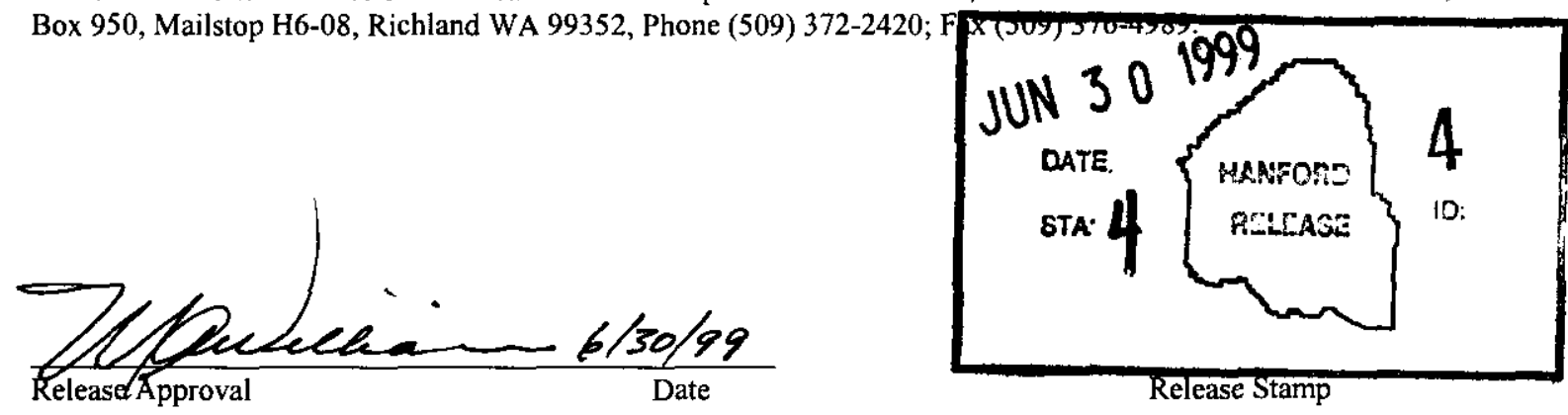


\section{REVIEW CHECKLIST}

\section{Document Reviewed:}

HNF-4465, Estimates of Particulate Mass for an MCO Containing Mark 1A Fuel

Rev. 0

Scope of Review:

Technical Review of Calculation

\section{Yes No NA}

O 0 - Previous reviews complete and cover analysis, up to scope of this review, with no gaps.

- 00 Problem completely defined.

000

Accident scenarios developed in a clear and logical manner.

0 O 00

Necessary assumptions explicitly stated and supported.

000

Computer codes and data files documented.

000

Data used in calculations explicitly stated in document.

0 O 0

Data checked for consistency with original source information as applicable.

000

Mathematical derivation checked including dimensional consistency of results.

000

Models appropriate and used within range of validity or use outside range of established validity justified.

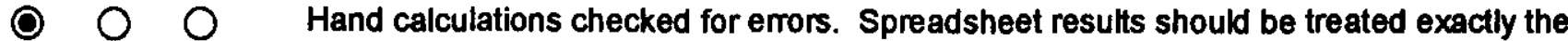
same as hand calculations.

$0 \quad 0 \quad 0$ Software input correct and consistent with document reviewed.

○ $\bigcirc$ Software output consistent with input and with results reported in document reviewed.

- 0 Limits/criteria/guidelines applied to analysis results are appropriate and referenced. Limits/criteria/guidelines checked against references.

- $\bigcirc ~ O ~ S a f e t y$ margins consistent with good engineering practices.

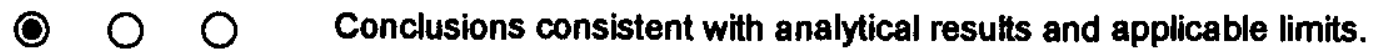

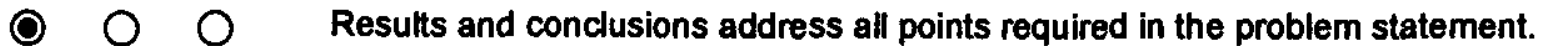

O $O \quad O$ Format consistent with appropriate NRC Regulatory Guide or other standards.

- $\bigcirc$ - Review calculations, comments, and/or notes are attached.

O $\bigcirc \quad$ Document approved.

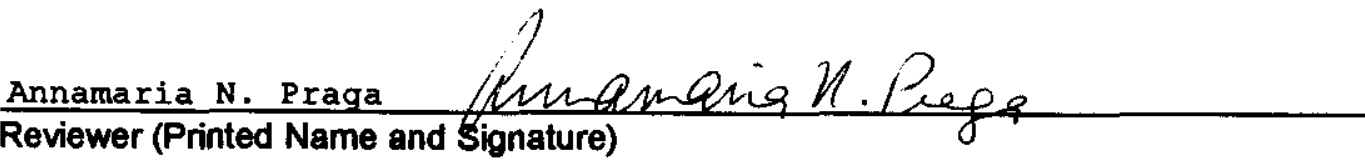

$\frac{6 / 10 / 99}{\text { Date }}$

*Any calculations, comments, or notes generated as part of this review should be signed, dated and attached to this checklist. Such material should be labeled and reconded in such a manner as to be intelligible to a technically qualified third party. 


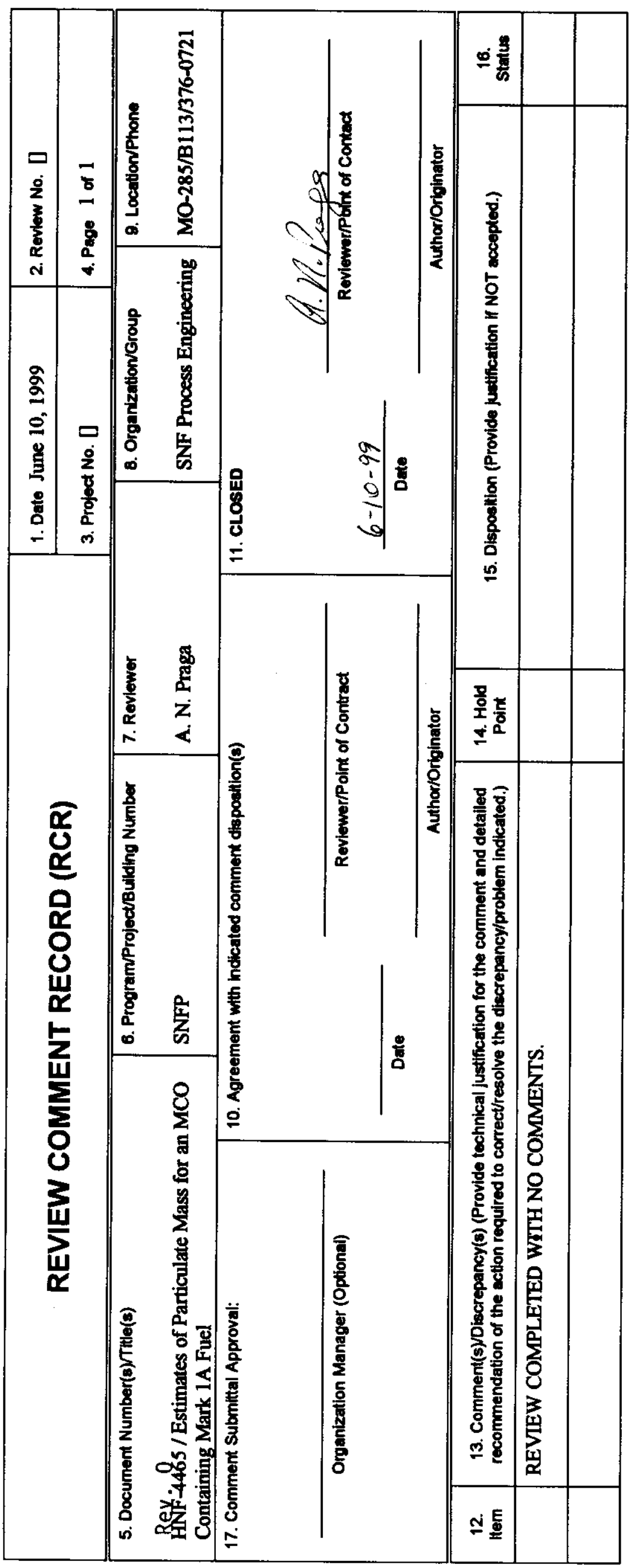

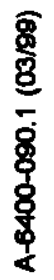




\section{TABLE OF CONTENTS}

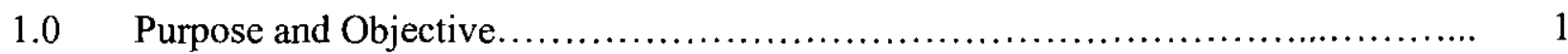

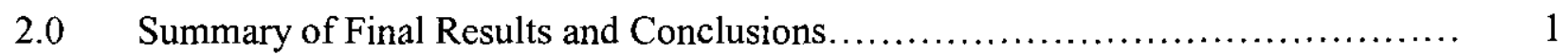

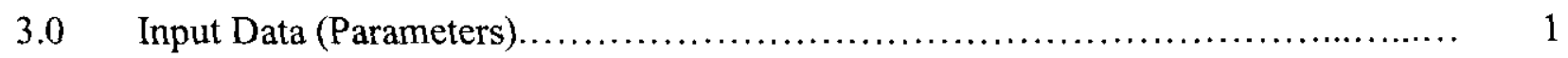

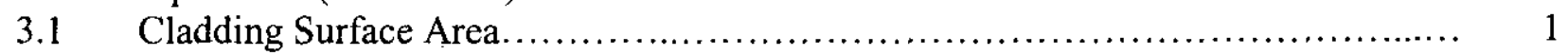

3.1.1 Cladding Surface Area of One Intact Fuel Assembly .......................... 1

3.1.2 Cladding Surface Area of One Scrap Basket.................................. 2

3.2 Uranium Surface Area .................................................... 2

$3.3 \quad$ Particulate Density .................................................... 3

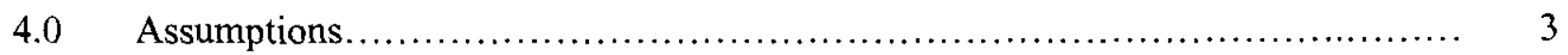

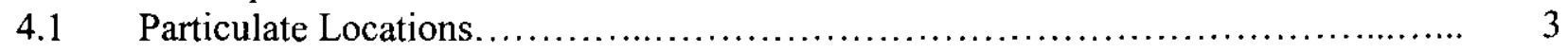

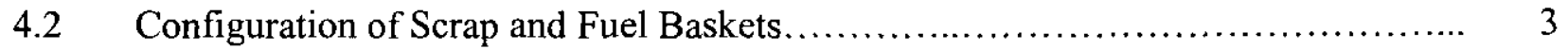

$4.3 \quad$ Estimates for Parameters. ................................................... 3

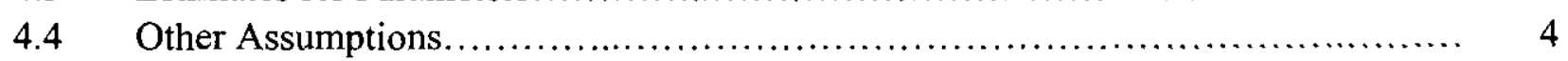

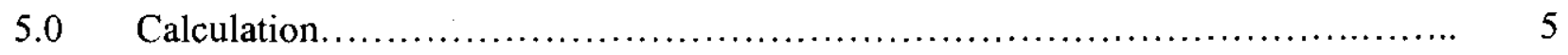

$5.1 \quad$ Scope of Calculation..................................................... 5

5.2 Mass Calculation Equations................................................... 5

$5.3 \quad$ Resulting Particulate Mass Values........................................ 7

5.3.1 Case 1: Zero Scrap Baskets - Six Fuel Baskets............................. 7

5.3.2 Case 2: One Scrap Basket - Five Fuel Baskets.............................. 7

5.3.3 Case 3: Two Scrap Baskets - Four Fuel Baskets............................ 9

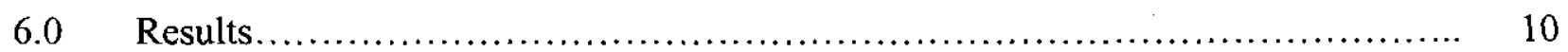

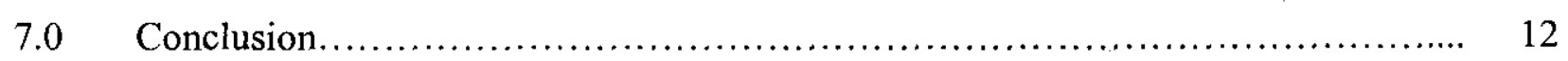

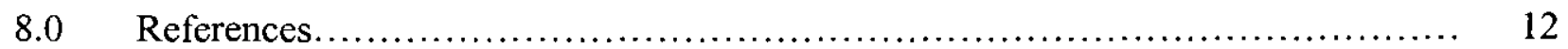

\section{LIST OF TABLES}

Table 3-1 Surface Area of Cladding for Mark 1A Fuel Assembly..................... 1

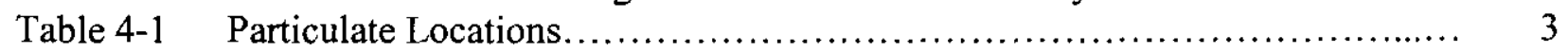

Table 4-2 Estimated Parameters................................................... 4

Table 6-1 Summary of Derived Particulate Mass Values for Mark 1A Fuel............. 11

Table 7-1 Comparison of Results for Mark 1A Fuel and Mark IV Fuel................ 12 


\subsection{Purpose and Objective}

The purpose of this calculation document is to determine the particulate mass associated with Mark 1A fuel. This document will also verify that the estimates for particulate mass for the Mark IV fuel loaded in a Multi-Canister Overpack (MCO) bound the estimates of particulate mass for the Mark 1A fuel. This document follows the form specified in HNF-1613 EP 7.6.

\subsection{Summary of Final Results and Conclusions}

The calculations show that the particulate inventory of an MCO containing Mark IV fuel bounds an MCO containing Mark 1A fuel. The calculations performed for the Mark 1A fuel use methods and assumptions consistent with those used by Sloughter 1998. Table 6-1 summarizes the estimates of particulate mass that were calculated for the Mark $1 \mathrm{~A}$ fuel. Table 7-1 illustrates the bounding results with a comparison of the total particulate mass for the two fuel types.

\subsection{Input Data (Parameters)}

Cladding surface area, uranium surface area, and particulate density are important parameters for this analysis.

\subsection{Cladding Surface Area}

The parameter for cladding surface area must be considered for both intact fuel assemblies and for the scrap fuel basket.

\subsubsection{Cladding Surface Area of One Intact Fuel Assembly}

The cladding surface area of intact fuel is calculated from the dimensions given below (Sloughter 1998).

$\begin{aligned} & \text { Maximum Length }=53.1 \mathrm{~cm} \\ & \text { Outer Diameter of Outer Element }=6.10 \mathrm{~cm} \\ & \text { Inner Diameter of Outer Element }=4.50 \mathrm{~cm} \\ & \text { Outer Diameter of Inner Element }=3.18 \mathrm{~cm} \\ & \text { Inner Diameter of Inner Element }=1.11 \mathrm{~cm} \\ & 1 \text { There are 12 Mark IA assemblies that are } 66.3 \mathrm{~cm} \text { in length which are stored in the K West Basin and are excluded from this analysis. }\end{aligned}$

Table 3-1. Surface Area of Cladding for Mark 1A Fuel Assembly

\begin{tabular}{|c|c|c|}
\hline Area of Outer Element's Outer Diameter & $\begin{array}{l}\text { height } \times(\pi \times \text { diameter }) \\
53.1 \mathrm{~cm} \times(\pi \times 6.10 \mathrm{~cm})\end{array}$ & $1017.6 \mathrm{~cm}^{2}$ \\
\hline Area of Outer Element's Inner Diameter & $53.1 \mathrm{~cm} \times(\pi \times 4.50 \mathrm{~cm})$ & $750.7 \mathrm{~cm}^{2}$ \\
\hline Area of Outer Element's End & $\begin{array}{c}2 \times\left[\left(\pi \times \mathrm{r}^{2}\right)_{\mathrm{OD}}-\left(\pi \times \mathrm{rr}^{2}\right)_{\mathrm{ID}}\right] \\
2 \times\left[\pi \times(6.10 / 2)^{2} \mathrm{~cm}^{2}-\pi \times(4.50 / 2)^{2} \mathrm{~cm}^{2}\right] \\
2 \times\left[29.2 \mathrm{~cm}^{2}-15.9 \mathrm{~cm}^{2}\right]\end{array}$ & $26.6 \mathrm{~cm}^{2}$ \\
\hline Area of Inner Element's Outer Diameter & $53.1 \mathrm{~cm} \times(\pi \times 3.18 \mathrm{~cm})$ & $530.5 \mathrm{~cm}^{2}$ \\
\hline Area of Inner Element's Inner Diameter & $53.1 \mathrm{~cm} \times(\pi \times 1.11 \mathrm{~cm})$ & $185.2 \mathrm{~cm}^{2}$ \\
\hline Area of Inner Element's End & $\begin{array}{c}2 \times\left[\left(\pi \times \mathrm{r}^{2}\right)_{\mathrm{OD}}-\left(\pi \times \mathrm{r}^{2}\right)_{\mathrm{ID}}\right] \\
2 \times\left[\pi \times(3.18 / 2)^{2} \mathrm{~cm}^{2}-\pi \times(1.11 / 2)^{2} \mathrm{~cm}^{2}\right] \\
2 \times\left[7.9 \mathrm{~cm}^{2}-1.0 \mathrm{~cm}^{2}\right]\end{array}$ & $13.9 \mathrm{~cm}^{2}$ \\
\hline \multicolumn{2}{|c|}{ Total Cladding Area of One Intact Fuel Assembly } & $2524.5 \mathrm{~cm}^{2}$ \\
\hline
\end{tabular}




\subsubsection{Cladding Surface Area of One Scrap Basket}

The cladding surface area in a scrap basket is calculated based on the number of equivalent assemblies that could be in a scrap basket. The number of equivalent assemblies is calculated by dividing the maximum weight allowed in a scrapbasket for criticality purposes by the weight of a full length Mark 1A assembly to arrive at a value of equivalent assemblies.

Calculate total weight of a full length Mark 1A fuel assembly (Sloughter 1998):

$$
\begin{array}{lll}
\text { Cladding }=0.88 \mathrm{~kg} \text { (Outer) }+0.54 \mathrm{~kg} \text { (Inner) } & =1.42 \mathrm{~kg} \\
\text { Fuel }=11.1 \mathrm{~kg} \text { (Outer) }+5.49 \mathrm{~kg} \text { (Inner) } & =16.59 \mathrm{~kg} \\
\text { Total Weight } & -
\end{array}
$$

Calculate number of equivalent assemblies in scrap basket:

$575 \mathrm{~kg}$ (maximum weight; Reilly 1998) $\div 18.01 \mathrm{~kg}$ (weight of assembly)

$=31.9$ equivalent assemblies

The analysis above provides for the maximum number of equivalent elements and the maximum cladding surface area that can be loaded into a scrap basket, based on the criticality limits.

\subsection{Uranium Surface Area}

Uranium surface area estimates are based on bounding estimates for Mark IV fuel and scrap baskets, modified to reflect fuel loading differences. The Mark IV basket data are consistent with Sloughter 1998. The modifications to describe Mark 1A baskets are shown below. An upper bound of $26,400 \mathrm{~cm}^{2}$ per basket has been estimated for scrap baskets, and $5,600 \mathrm{~cm}^{2}$ has been estimated for fuel baskets (Ball 1998).

Note that the Mark IV fuel information has been obtained from Ball 1998 and Sloughter 1998.

Calculate surface area of scrap basket:

- High

- Best Est. $10,000 \mathrm{~cm}^{2} /$ basket

- Low

$$
26,400 \mathrm{~cm}^{2} / \text { basket } \quad\left(\frac{45,000 \mathrm{~cm}^{2}}{980 \mathrm{~kg}}\right)(\text { Mark IV) x } 575 \mathrm{~kg} \text { (Mark 1A) }
$$$$
\left(\frac{17,000 \mathrm{~cm}^{2}}{980 \mathrm{~kg}}\right)(\text { Mark IV) x } 575 \mathrm{~kg}(\text { Mark 1A) }
$$

Scrap can consist of damaged assemblies with few "fine" fragments by its definition. No calculation was performed for this value, it is just an estimate. 
Calculate surface area of fuel basket:

- High $\quad 5,600 \mathrm{~cm}^{2} /$ basket $\quad\left(\frac{48 \text { assem } \times 2524 \mathrm{~cm}^{2}(M k 1 A)}{54 \text { assem. } \times 3156 \mathrm{~cm}^{2}(M k I V)}\right) \times 7,900 \mathrm{~cm}^{2}(\mathrm{Mk} \mathrm{IV})$

- Best Est. $\quad 300 \mathrm{~cm}^{2} /$ basket $\quad\left(\frac{48 \text { assem. } \times 2524 \mathrm{~cm}^{2}(M k 1 \mathrm{~A})}{54 \text { assem. } \times 3156 \mathrm{~cm}^{2}(M k I V)}\right) \times 425 \mathrm{~cm}^{2}$ (Mk IV)

- Low $\quad 110 \mathrm{~cm}^{2} /$ basket $\quad\left(\frac{48 \text { assem. } \times 2524 \mathrm{~cm}^{2}(M k 1 A)}{54 \text { assem. } \times 3156 \mathrm{~cm}^{2}(M k I V)}\right) \times 160 \mathrm{~cm}^{2}(\mathrm{Mk} \mathrm{IV})$

\subsection{Particulate Density}

Consistent with the calculations in Sloughter 1998,

- The adhering particulate mass is based on the density of Uranium Dioxide, $10 \mathrm{~g} / \mathrm{cm}^{3}$.

- The canister particulate mass is based on the bulk density of $\mathrm{KW}$ Basin canister particulate, $2.7 \mathrm{~g} / \mathrm{cm}^{3}$ (Pearce 1998).

\subsection{Assumptions}

\subsection{Particulate Locations}

Particulate locations, as discussed in Sloughter 1998, are summarized in Table 4-1.

Table 4-1. Particulate Locations

\begin{tabular}{|c|c|c|c|}
\hline MCO Location & Films & Adhering Particulates & Canister Particulate \\
\hline Scrap Basket & $\begin{array}{c}\text { On cladding and exposed } \\
\text { uranium surfaces }\end{array}$ & $\begin{array}{c}\text { On uranium surfaces } \\
\text { within/around damage areas }\end{array}$ & $\begin{array}{c}\text { N/A - See Sloughter } \\
1998, \text { section 5.2.3.1 }\end{array}$ \\
\hline Fuel Baskets & $\begin{array}{c}\text { On cladding and exposed } \\
\text { uranium surfaces }\end{array}$ & $\begin{array}{c}\text { On uranium surfaces } \\
\text { within/around damage areas }\end{array}$ & Within flow channels \\
\hline
\end{tabular}

\subsection{MCO Loading Configurations}

Three MCO loading configurations are considered by this calculation. These are discussed in Sloughter 1998. The difference between MCOs containing Mark IV fuel and MCOs containing Mark 1A fuel is that they hold a maximum of five baskets and six baskets, respectively. For the Mark $1 \mathrm{~A} \mathrm{MCO}$, case 1 considers zero scrap baskets and six fuel baskets. Case 2 considers one scrap basket and five fuel baskets. Case 3 considers two scrap baskets and four fuel baskets.

\subsection{Estimates for Parameters}

The estimated parameters are listed in Table 4-2. 
Table 4-2. Estimated Parameters

\begin{tabular}{|c|c|c|c|c|c|}
\hline & & High & Best Estimate & Low & Reference \\
\hline \multicolumn{2}{|l|}{ Cladding Surface Film } & $12.5 \mathrm{mg} / \mathrm{cm}^{2}$ & $3.54 \mathrm{mg} / \mathrm{cm}^{2}$ & $0.55 \mathrm{mg} / \mathrm{cm}^{2}$ & Sloughter 1998 \\
\hline Uranium Surface Film & Thickness & $10 \mu \mathrm{m}$ & $3 \mu \mathrm{m}$ & $3 \mu \mathrm{m}$ & Sloughter 1998 \\
\hline \multirow{2}{*}{ Uranium Surface Area } & Scrap & $26,400 \mathrm{~cm}^{2} /$ basket & $10,000 \mathrm{~cm}^{2} /$ basket & $5,000 \mathrm{~cm}^{2} /$ basket & Section 3.1.2 \\
\hline & Fuel & $5,600 \mathrm{~cm}^{2} /$ basket & $300 \mathrm{~cm}^{2} /$ basket & $110 \mathrm{~cm}^{2} /$ basket & Section 3.1.2 \\
\hline \multirow[t]{2}{*}{ Adhering Particulate } & Scrap & $200 \mathrm{~g}$ & $20 \mathrm{~g}$ & $6 \mathrm{~g}$ & Sloughter 1998 \\
\hline & Fuel & $20 \mathrm{~g}$ & $7.6 \mathrm{~g}$ & $1.3 \mathrm{~g}$ & Sloughter 1998 \\
\hline \multirow[t]{2}{*}{ Canister Particulate } & Scrap & $\overline{0}$ & 0 & 0 & Sloughter 1998 \\
\hline & Fuel $^{1}$ & $310 \mathrm{~g} /$ basket & $140 \mathrm{~g} /$ basket & 0 & Sloughter 1998 \\
\hline
\end{tabular}

1 The methodology for calculating canister particulate for the fuel baskets follows Sloughter 1998 with modifications for Mark 1A fuel loading:

Calculate volume of canister particulate:

$$
\begin{aligned}
\mathrm{V}_{\text {tol }} & =V_{\text {irne }}+V_{\text {annulus }}=\left(\mathrm{h} \times \pi \times \mathrm{r}_{\text {inner }}^{2}\right)+\left(\mathrm{h} \times \pi \times\left(\mathrm{r}_{\text {oulco }}^{2}-\mathrm{r}_{\text {innog }}^{2}\right)\right) \\
& =\left(7.6 \mathrm{~cm} \times \pi \times(1.11 / 2)^{2} \mathrm{~cm}^{2}\right)+\left(7.6 \mathrm{~cm} \times \pi \times\left((4.50 / 2)^{2} \mathrm{~cm}^{2}-(3.18 / 2)^{2} \mathrm{~cm}^{2}\right)\right)=68 \mathrm{~cm}^{3}
\end{aligned}
$$

Calculate the volume of canister particulate:

$1.3 \mathrm{~cm}^{3}$ (volume of canister particulate) $\times 406$ assemblies per batch $=528 \mathrm{~cm}^{3}$ canister particulate;

$0.15 \times 29$ canisters per batch $\times 68 \mathrm{~cm}^{3}$ per assembly $=296 \mathrm{~cm}^{3}$ canister particulate;

2 assemblies $\times 68 \mathrm{~cm}^{3}$ per assembly $=136 \mathrm{~cm}^{3}$ canister particulate.

$528 \mathrm{~cm}^{3}+296 \mathrm{~cm}^{3}+136 \mathrm{~cm}^{3}=960 \mathrm{~cm}^{3}$ canister particulate per batch.

Calculate the maximum volume of canister particulate loaded into one fuel basket, based on 48 assemblies per basket (Smith 1998): $960 \mathrm{~cm}^{3} \times\left(48\right.$ assemblies per fuel basket $\div 406$ assemblies per batch) $=114 \mathrm{~cm}^{3} /$ basket.

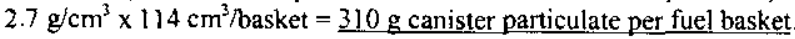

Calculate the best estimate volume of canister particulate loaded into one fuel basket.

$296 \mathrm{~cm}^{3}+136 \mathrm{~cm}^{3}=432 \mathrm{~cm}^{3}$ canister particulate per 406 assembly validation batch.

(48 assemblies per basket $\div 406$ assemblies per batch) $\times 432 \mathrm{~cm}^{3}$ per batch $=51 \mathrm{~cm}^{3}$ per basket.

$2.7 \mathrm{~g} / \mathrm{cm}^{3} \times 51 \mathrm{~cm}^{3} /$ basket $=140 \mathrm{~g} \mathrm{canister} \mathrm{particulate} \mathrm{per} \mathrm{fuel} \mathrm{basket.}$

\subsection{Other Assumptions}

Other key assumptions used in this analysis, from Sloughter 1998, are restated below:

- Fuel elements described as "bad" are assumed to be placed in scrap baskets (Pitner 1998).

- Formation of white layers in local spots and the presence of local reddish spots are considered to be included in the high estimates.

- While no credit is taken for the cleaning equipment's ability to remove any of the white layer that was measured on fuel element samples, the estimate does assume that the cleaning process will be at least as effective as the limited cleaning obtained from transporting the fuel elements to the laboratory.

- The above statement should not be taken to imply that "adhering particulate" would be readily available for release from an $\mathrm{MCO}$. What it does imply is that the adhering particulate estimate is both reasonable (in that it does not include the particulate that was found on the bottom of the transfer cask) and conservative (in that it does include all of the particulate that was recovered from the sample, even though the sample had not been cleaned). The adhering particulate category is intended to represent only those materials that are very difficult to remove. 


\subsection{Calculation}

5.1 Scope of Calculation

The calculation, consistent with Sloughter 1998, considers materials that may be loaded into an $\mathrm{MCO}$ that are literally not cladding and fuel in their original form.

\subsection{Mass Calculation Equations}

Particulate masses are calculated for cladding and uranium surface area films, adhering particulates, and canister particulate deposits loaded into the MCO. The mass values are calculated for scrap and fuel.

\subsubsection{Cladding Surface Films (Scrap)}

The associated mass is given by:

where,

$$
M_{\text {layer }}=A_{\text {assy } \times} N_{\text {assy } \times}(m / A)_{\text {layer }}
$$

$$
\begin{array}{rll}
\mathrm{M}_{\text {layer }} & =\text { Layer mass } & (\mathrm{kg}) \\
\mathrm{A}_{\text {assy }} & =\text { Assembly area } & \left(\mathrm{cm}^{2}\right) \\
\mathrm{N}_{\text {assy }} & =\text { Number of assemblies } & (\text { fuel plus scrap }) \\
(\mathrm{m} / \mathrm{A})_{\text {layer }} & =\text { Mass per unit area of layer } & \left(\mathrm{kg} / \mathrm{cm}^{2}\right)
\end{array}
$$

The area of an assembly is from section 3.1.1:

$$
\mathrm{A}_{\mathrm{assy}}=2524.5 \mathrm{~cm}^{2}
$$

The number of equivalent assemblies in a scrap basket is from section 3.1.2:

$$
\mathrm{N}_{\text {assy, scrap }}=(575 \mathrm{~kg} / \text { scrap basket }) \div(18.01 \mathrm{~kg} / \text { assembly }) \quad=31.9
$$

Mass per unit area of the layer values are defined in section 4.3.

\subsubsection{Cladding Surface Film (Fuel)}

The associated mass is given by Equation 1, with the exception that the number of fuel assemblies is taken as the sum of fuel assemblies for an MCO with four, five, or six fuel baskets:

$$
\begin{array}{ll}
\mathrm{N}_{\text {assy, fuel }}=4 \text { fuel baskets } \times 48 \text { fuel assemblies per basket } & =192 \\
\mathrm{~N}_{\text {assy, fuel }}=5 \text { fuel baskets } \times 48 \text { fuel assemblies per basket } & =240 \\
\mathrm{~N}_{\text {assy, fuel }}=6 \text { fuel baskets } \times 48 \text { fuel assemblies per basket } & =288
\end{array}
$$

\subsubsection{Uranium Surface Film (Scrap)}

All exposed uranium metal should have some oxide film because some corrosion must have occurred. Scrap is considered separately from fuel because the area for scrap is deduced differently than the area for fuel. The mass of an oxide layer is given by: 
HNF-4465, Rev. 0

Page 6 of 12

where,

$$
M_{\text {ox }, \text { scrap }}=A_{\text {ox, scrap } x}(\mathrm{~m} / \mathrm{A})_{\mathrm{ox}}
$$

(Equation 2)

$$
\begin{array}{rll}
\mathrm{M}_{\mathrm{ox}, \text { scrap }} & =\text { Oxide mass on scrap } & (\mathrm{kg}) \\
\mathrm{A}_{\mathrm{ox}, \text { scrap }} & =\text { Oxidation area of scrap } & \left(\mathrm{m}^{2}\right) \\
(\mathrm{m} / \mathrm{A})_{\mathrm{ox}} & =\text { Mass per unit area oxide layer } & \left(\mathrm{kg} / \mathrm{m}^{2}\right)
\end{array}
$$

The area $\mathrm{A}_{\mathrm{ox} \text {, scrap }}$ is chosen as discussed in section 4.3.

The mass per unit area is further decomposed as the product of layer thickness and density:

where,

$$
(\mathrm{m} / \mathrm{A})_{\mathrm{ox}}=\rho_{\text {layer }} \times \delta_{\text {layer }}
$$

$$
\begin{array}{ll}
\rho_{\text {layer }}=\text { Layer density } & \left(\mathrm{kg} / \mathrm{m}^{3}\right) \\
\delta_{\text {layer }}=\text { Layer thickness } & (\mathrm{cm})
\end{array}
$$

\subsubsection{Uranium Surface Film (Fuel)}

Fuel in fuel baskets has areas with cladding failure and the exposed metal must have some oxide layer. The mass of this oxide is given by the same formula as for the scrap basket oxide:

$$
\mathrm{M}_{\mathrm{ox}, \text { fuel }}=\mathrm{A}_{\mathrm{ox}, \text { fuel } \mathrm{x}}(\mathrm{m} / \mathrm{A})_{\mathrm{ox}}
$$

The exposed area is defined in section 4.3 and the mass per unit area is chosen the same way as for that in the scrap basket.

\subsubsection{Particulate on Scrap}

Particulate is found to be associated with failed areas, both on the failed area and underneath the adjacent cladding that has become unbonded from the fuel. Particulates associated with fuel and scrap are considered separately because the damage in scrap is more extensive than it is in fuel. The mass of particulate associated with scrap is given by:

where,

$$
\mathrm{M}_{\text {par, scrap }}=\mathrm{N}_{\text {assy, scrap } \times} \mathrm{m}_{\text {par, assy }}
$$

$$
\begin{array}{rll}
\mathrm{M}_{\text {par, scrap }} & =\text { Particulate mass on scrap } & (\mathrm{kg}) \\
\mathrm{m}_{\text {par, assy }} & =\text { Mass of particulate per assembly } & (\mathrm{kg})
\end{array}
$$

The mass of particulate per assembly in a scrap basket is given in section 4.3 .

\subsubsection{Particulate on Fuel}

Similarly, particulate may be found on the failed area and locally underneath adjacent cladding on fuel assemblies in fuel baskets, and the total mass is:

$$
M_{\text {par, fuel }}=N_{\text {assy, fuel }} \times m_{\text {par, assy }}
$$

The mass of particulate per assembly in a fuel basket is given in section 4.3. 
5.3 Resulting Particulate Mass Values

Calculations of particulate values (on an MCO basis) are shown below for three cases.

Results are rounded to yield the overall values summarized in Table 6-1.

\subsubsection{Case 1: Zero Scrap Baskets - Six Fuel Baskets}

5.3.1.1 Cladding Surface Film (Fuel)

High:

Best Est.:
$2524.5 \mathrm{~cm}^{2} /$ assy $x 288$ assy $x 1.25 \mathrm{E}-5 \mathrm{~kg} / \mathrm{cm}^{2}$

$2524.5 \mathrm{~cm}^{2} /$ assy $\times 288$ assy $\times 3.54 \mathrm{E}-6 \mathrm{~kg} / \mathrm{cm}^{2}$
[Equation 1]

$=9.088 \mathrm{~kg}$

$=2.574 \mathrm{~kg}$

Best Estimate Calculation for Break Down by Film Type Reported in Table 6.1 $\mathrm{Al}(\mathrm{OH})_{3}: \quad 2524.5 \mathrm{~cm}^{2} /$ assy $\times 0.25 \times 288$ assy $\times 1.25 \mathrm{E}-5 \mathrm{~kg} / \mathrm{cm}^{2}=2.272 \mathrm{~kg}$ $\mathrm{UO}_{\mathrm{x}}: \quad 2524.5 \mathrm{~cm}^{2} /$ assy $\times 0.75 \times 288$ assy $\times 5.5 \mathrm{E}-7 \mathrm{~kg} / \mathrm{cm}^{2} \quad=0.300 \mathrm{~kg}$ Low: $=0.400 \mathrm{~kg}$

5.3.1.2 Uranium Surface Film (Fuel)

[Equation 4]

High: $\quad 5600 \mathrm{~cm}^{2} /$ basket $\times 6$ baskets $\times 10 \mathrm{E}-4 \mathrm{~cm} \times 0.01 \mathrm{~kg} / \mathrm{cm}^{3}=0.336 \mathrm{~kg}$ Best Est.: $\quad 300 \mathrm{~cm}^{2} /$ basket $\times 6$ baskets $\times 3 \mathrm{E}-4 \mathrm{~cm} \times 0.01 \mathrm{~kg} / \mathrm{cm}^{3} \quad=0.005 \mathrm{~kg}$ Low: $\quad 110 \mathrm{~cm}^{2} /$ basket $\times 6$ baskets $\times 3 E-4 \mathrm{~cm} \mathrm{x} 0.01 \mathrm{~kg} / \mathrm{cm}^{3}=0.002 \mathrm{~kg}$

5.3.1.3 Particulate on Fuel

[Equation 6]

High: $0.0200 \mathrm{~kg} /$ assy $\mathrm{x} 288$ assy $=5.760 \mathrm{~kg}$

Best Est.: $0.0076 \mathrm{~kg} /$ assy $\mathrm{x} 288$ assy

$=2.189 \mathrm{~kg}$

Low: $0.0013 \mathrm{~kg} /$ assy x 288 assy

$=0.374 \mathrm{~kg}$

5.3.1.4 Canister Particulate

[Equation 6]

High:

6 baskets x $0.310 \mathrm{~kg} /$ basket

Best Est.:

6 baskets $\mathrm{x} 0.140 \mathrm{~kg} /$ basket

$=1.860 \mathrm{~kg}$

Low:

6 baskets $\mathrm{x} 0 \mathrm{~kg} / \mathrm{basket}$

$=0.840 \mathrm{~kg}$

$=0 \mathrm{~kg}$

5.3.2 Case 2: One Scrap Basket - Five Fuel Baskets

5.3.2.1 Cladding Surface Film (Scrap)

[Equation 1]

High: $\quad 2524.5 \mathrm{~cm}^{2} /$ assy $\times 31.9$ assy $\times 1.25 \mathrm{E}-5 \mathrm{~kg} / \mathrm{cm}^{2} \quad=1.007 \mathrm{~kg}$ Best Est.: $\quad 2524.5 \mathrm{~cm}^{2} /$ assy $\quad 31.9$ assy $\times 3.54 \mathrm{E}-6 \mathrm{~kg} / \mathrm{cm}^{2} \quad=0.285 \mathrm{~kg}$

Best Estimate Calculation for Break Down by Film Type Reported in Table 6.1
$\mathrm{Al}(\mathrm{OH})_{3}$ :
$2524.5 \mathrm{~cm}^{2} /$ assy x $0.25 \times 31.9$ assy $\times 1.25 \mathrm{E}-5 \mathrm{~kg} / \mathrm{cm}^{2}$
$=0.252 \mathrm{~kg}$
$\mathrm{UO}_{\mathrm{x}}$ :
$2524.5 \mathrm{~cm}^{2} /$ assy $\times 0.75 \times 31.9$ assy $\times 5.5 \mathrm{E}-7 \mathrm{~kg} / \mathrm{cm}^{2}$
$=0.033 \mathrm{~kg}$
$2524.5 \mathrm{~cm}^{2} /$ assy x 31.9 assy $\times 5.5 \mathrm{E}-7 \mathrm{~kg} / \mathrm{cm}^{2}$
$=0.044 \mathrm{~kg}$

Low: 
High: $\quad 2524.5 \mathrm{~cm}^{2} /$ assy $\quad 240$ assy $\times 1.25 \mathrm{E}-5 \mathrm{~kg} / \mathrm{cm}^{2} \quad=7.573 \mathrm{~kg}$ Best Est.: $\quad 25.24 .5 \mathrm{~cm}^{2} /$ assy $\quad 240$ assy $\times 3.54 \mathrm{E}-6 \mathrm{~kg} / \mathrm{cm}^{2} \quad=2.145 \mathrm{~kg}$

Best Estimate Calculation for Break Down by Film Type Reported in Table 6.1

$\mathrm{Al}(\mathrm{OH})_{3}: \quad 2524.5 \mathrm{~cm}^{2} /$ assy $\times 0.25 \times 240$ assy $\times 1.25 \mathrm{E}-5 \mathrm{~kg} / \mathrm{cm}^{2}=1.893 \mathrm{~kg}$ $\begin{array}{lcl}2524.5 \mathrm{~cm}^{2} / \text { assy } \times 0.75 \times 240 \text { assy } \times 5.5 \mathrm{E}-7 \mathrm{~kg} / \mathrm{cm}^{2} & =0.250 \mathrm{~kg} \\ \text { Low: } \quad 2524.5 \mathrm{~cm}^{2} / \text { assy } \times 240 \text { assy } \times 5.5 \mathrm{E}-7 \mathrm{~kg} / \mathrm{cm}^{2} & =0.333 \mathrm{~kg}\end{array}$

5.3.2.3 Uranium Surface Film (Scrap)

[Equation 2]

High: $\quad 26400 \mathrm{~cm}^{2} /$ basket $\times 1$ baskets $\times 10 \mathrm{E}-4 \mathrm{~cm} \mathrm{x} 0.01 \mathrm{~kg} / \mathrm{cm}^{3}=0.264 \mathrm{~kg}$ Best Est.: $\quad 10000 \mathrm{~cm}^{2} /$ basket $\times 1$ baskets $\times 3 E-4 \mathrm{~cm} \times 0.01 \mathrm{~kg} / \mathrm{cm}^{3}=0.030 \mathrm{~kg}$ Low: $\quad 5000 \mathrm{~cm}^{2} /$ basket $\times 1$ baskets $\times 3 E-4 \mathrm{~cm} \times 0.01 \mathrm{~kg} / \mathrm{cm}^{3}=0.015 \mathrm{~kg}$

5.3.2.4 Uranium Surface Film (Fuel)

[Equation 4]

High: $\quad 5600 \mathrm{~cm}^{2} /$ basket $\times 5$ baskets $\times 10 \mathrm{E}-4 \mathrm{~cm} \times 0.01 \mathrm{~kg} / \mathrm{cm}^{3}=0.280 \mathrm{~kg}$ Best Est.: $\quad 300 \mathrm{~cm}^{2} /$ basket $\times 5$ baskets $\times 3 \mathrm{E}-4 \mathrm{~cm} \times 0.01 \mathrm{~kg} / \mathrm{cm}^{3} \quad=0.005 \mathrm{~kg}$ Low: $\quad 110 \mathrm{~cm}^{2} /$ basket $\times 5$ baskets $\times 3 \mathrm{E}-4 \mathrm{~cm} \times 0.01 \mathrm{~kg} / \mathrm{cm}^{3}=0.002 \mathrm{~kg}$

5.3.2.5 Particulate on Scrap

[Equation 5]

High:

Best Est.:

Low:

5.3.2.6 Particulate on Fuel

High:

Best Est.:

Low:

5.3.2.7 Canister Particulate

High:

Best Est.:

Low:
$0.200 \mathrm{~kg} /$ assy x 31.9 assy

$0.020 \mathrm{~kg} /$ assy $\times 31.9$ assy

$0.006 \mathrm{~kg} /$ assy x 31.9 assy

$0.0200 \mathrm{~kg} /$ assy x 240 assy

$0.0076 \mathrm{~kg} /$ assy x 240 assy

$0.0013 \mathrm{~kg} /$ assy x 240 assy

5 baskets $x 0.310 \mathrm{~kg} /$ basket

5 baskets $\times 0.140 \mathrm{~kg} /$ basket

5 baskets x $0 \mathrm{~kg} /$ basket
$=6.380 \mathrm{~kg}$

$=0.638 \mathrm{~kg}$

$=0.191 \mathrm{~kg}$

[Equation 6]

$=4.800 \mathrm{~kg}$

$=1.824 \mathrm{~kg}$

$=0.312 \mathrm{~kg}$

[Equation 6]

$=1.550 \mathrm{~kg}$

$=0.700 \mathrm{~kg}$

$=0 \mathrm{~kg}$ 
5.3.3 Case 3: Two Scrap Baskets - Four Fuel Baskets

5.3.3.1 Cladding Surface Film (Scrap)

[Equation 1]

$\begin{array}{lll}\text { High: } & 2524.5 \mathrm{~cm}^{2} / \text { assy x } 63.8 \text { assy } \times 1.25 \mathrm{E}-5 \mathrm{~kg} / \mathrm{cm}^{2} & =2.013 \mathrm{~kg} \\ \text { Best Est.: } & 2524.5 \mathrm{~cm}^{2} / \text { assy } \times 63.8 \text { assy } \times 3.54 \mathrm{E}-6 \mathrm{~kg} / \mathrm{cm}^{2} & =0.570 \mathrm{~kg}\end{array}$

Best Estimate Calculation for Break Down by Film Type Reported in Table 6.1

$\mathrm{Al}(\mathrm{OH})_{3}: \quad 2524.5 \mathrm{~cm}^{2} /$ assy $\times 0.25 \times 63.8$ assy $\times 1.25 \mathrm{E}-5 \mathrm{~kg} / \mathrm{cm}^{2}=0.503 \mathrm{~kg}$ $\mathrm{UO}_{\mathrm{x}}: \quad 2524.5 \mathrm{~cm}^{2} /$ assy $\mathrm{x} 0.75 \times 63.8$ assy $\times 5.5 \mathrm{E}-7 \mathrm{~kg} / \mathrm{cm}^{2}=0.066 \mathrm{~kg}$

Low: $\quad 2524.5 \mathrm{~cm}^{2} /$ assy $x 63.8$ assy $\times 5.5 \mathrm{E}-7 \mathrm{~kg} / \mathrm{cm}^{2} \quad=0.089 \mathrm{~kg}$

5.3.3.2 Cladding Surface Film (Fuel)

[Equation 1]

$\begin{array}{lll}\text { High: } & 2524.5 \mathrm{~cm}^{2} / \text { assy } \times 192 \text { assy } \times 1.25 \mathrm{E}-5 \mathrm{~kg} / \mathrm{cm}^{2} & =6.059 \mathrm{~kg} \\ \text { Best Est.: } & 2524.5 \mathrm{~cm}^{2} / \text { assy } \times 192 \text { assy } \times 3.54 \mathrm{E}-6 \mathrm{~kg} / \mathrm{cm}^{2} & =1.716 \mathrm{~kg}\end{array}$

Best Estimate Calculation for Break Down by Film Type Reported in Table 6.1

$\mathrm{Al}(\mathrm{OH})_{3}: \quad 2524.5 \mathrm{~cm}^{2} /$ assy $\times 0.25 \times 192$ assy $\times 1.25 \mathrm{E}-5 \mathrm{~kg} / \mathrm{cm}^{2}=1.515 \mathrm{~kg}$

Low: $\quad \begin{array}{lll}\mathrm{x} \cdot & 2524.5 \mathrm{~cm}^{2} / \text { assy } \times 192 \text { assy } \times 5.5 \mathrm{E}-7 \mathrm{~kg} / \mathrm{cm}^{2} & =0.267 \mathrm{~kg}\end{array}$

5.3.3.3 Uranium Surface Film (Scrap)

[Equation 2]

High: $\quad 26400 \mathrm{~cm}^{2}$ basket $\times 2$ baskets $\times 10 \mathrm{E}-4 \mathrm{~cm} \times 0.01 \mathrm{~kg} / \mathrm{cm}^{3}=0.528 \mathrm{~kg}$ Best Est.: $\quad 10000 \mathrm{~cm}^{2} /$ basket $\times 2$ baskets $\times 3 E-4 \mathrm{~cm} \times 0.01 \mathrm{~kg} / \mathrm{cm}^{3}=0.060 \mathrm{~kg}$ Low: $\quad 5000 \mathrm{~cm}^{2} /$ basket $\times 2$ baskets $\times 3 E-4 \mathrm{~cm} \times 0.01 \mathrm{~kg} / \mathrm{cm}^{3} \quad=0.030 \mathrm{~kg}$

5.3.3.4 Uranium Surface Film (Fuel)

[Equation 4]

High: $\quad 5600 \mathrm{~cm}^{2} /$ basket $\times 4$ baskets $\times 10 \mathrm{E}-4 \mathrm{~cm} \times 0.01 \mathrm{~kg} / \mathrm{cm}^{3}=0.224 \mathrm{~kg}$

Best Est.: $\quad 300 \mathrm{~cm}^{2} /$ basket $\times 4$ baskets $\times 3 \mathrm{E}-4 \mathrm{~cm} \times 0.01 \mathrm{~kg} / \mathrm{cm}^{3}=0.004 \mathrm{~kg}$

Low: $\quad 110 \mathrm{~cm}^{2} /$ basket $\times 4$ baskets $\times 3 E-4 \mathrm{~cm} \times 0.01 \mathrm{~kg} / \mathrm{cm}^{3}=0.001 \mathrm{~kg}$

5.3.3.5 Particulate on Scrap

[Equation 5]

High:

Best Est.:

Low:

5.3.3.6 Particulate on Fuel

High:

Best Est.:

Low:
$0.200 \mathrm{~kg} /$ assy x 63.8 assy

$0.020 \mathrm{~kg} /$ assy $\mathrm{x} 63.8$ assy

$0.006 \mathrm{~kg} /$ assy x 63.8 assy

$=12.76 \mathrm{~kg}$

$=1.276 \mathrm{~kg}$

$=0.383 \mathrm{~kg}$

[Equation 6]

$=3.840 \mathrm{~kg}$

$=1.459 \mathrm{~kg}$

$=0.250 \mathrm{~kg}$ 
HNF-4465, Rev. 0

Page 10 of 12

\subsubsection{Canister Particulate}

\section{High:}

Best Est.:

Low:
4 baskets $\times 0.310 \mathrm{~kg} /$ basket

4 baskets $\times 0.140 \mathrm{~kg} /$ basket

4 baskets $\times 0 \mathrm{~kg} /$ basket
[Equation 6]

$=1.240 \mathrm{~kg}$

$=0.560 \mathrm{~kg}$

$=0 \mathrm{~kg}$

\subsection{Results}

The results of the calculations in section 5.0 are summarized in Table 6-1. 
HNF-4465, Rev. 0

Page 11 of 12

Table 6-1. Summary of Derived Particulate Mass Values for Mark 1A Fuel (kg/MCO) ${ }^{1}$

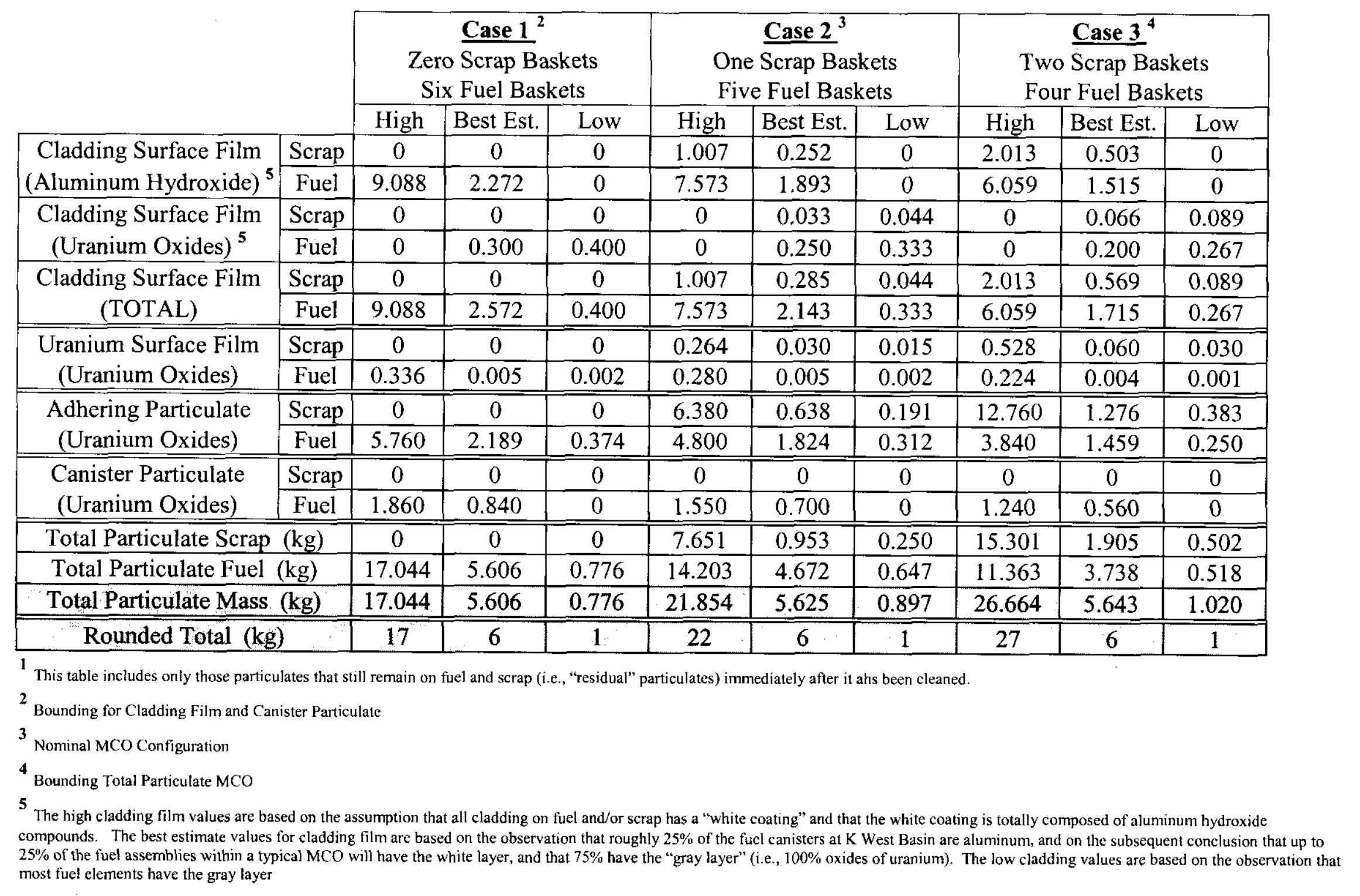




\subsection{Conclusion}

When the results from Table 6-1 are compared to those in Sloughter 1998, it is concluded that the estimates for particulate mass for the Mark IV fuel do indeed bound the estimates for particulate mass for the Mark 1A fuel. Table 6-2 summarizes these findings.

Table 7-1. Comparison of Results for Mark 1A Fuel and Mark IV Fuel

\begin{tabular}{|c|c|c|c|c|c|c|c|c|c|}
\cline { 2 - 9 } \multicolumn{1}{c|}{} & \multicolumn{2}{c|}{$\begin{array}{c}\text { Case 1 } \\
\text { Zero Scrap / } \\
\text { Six Fuel Baskets }\end{array}$} & \multicolumn{3}{c|}{$\begin{array}{c}\text { Case 2 } \\
\text { One Scrap / } \\
\text { Five Fuel Baskets }\end{array}$} & \multicolumn{3}{c|}{$\begin{array}{c}\text { Case 3 } \\
\text { Two Scrap / } \\
\text { Four Fuel Baskets }\end{array}$} \\
\cline { 2 - 10 } & High & Best Est. & Low & High & Best Est. & Low & High & Best Est. & Low \\
\hline Mark 1A Fuel & 17 & 6 & 1 & 22 & 6 & 1 & 27 & 6 & 1 \\
\hline Mark IV Fuel & 18 & 6 & 1 & 24 & 6 & 1 & 30 & 6 & 1 \\
\hline
\end{tabular}

\subsection{References}

Ball, D. E. and D. R. Duncan, 1998, Fuel Surface Area, HNF-SD-SNF-CN-017, Rev. 3, Duke Engineering and Services Hanford, Richland, Washington.

Pearce, K. L.,1998, 105-K Basin Material Design Basis Feed Description for Spent Nuclear Fuel Project Facilites, Volume 2, Sludge, HNF-SD-SNF-TI-009, Volume 2, Rev. 2, Numatec Hanford Corporation, Richland, Washington.

Pitner, A. L., 1998, Summary Assessment of Fuel Damage Distributions in the K Basins, HNF-2586, Rev. 0, Duke Engineering and Services Hanford, Richland, Washington.

Reilly, M. A., 1998, Spent Nuclear Fuel Project Technical Databook, HNF-SDSNF-TI-015, Rev. 5, Duke Engineering and Services Hanford, Richland, Washington.

Sloughter, J. P., 1998, Estimates of Particulate Mass in Multi-Canister Overpacks, HNF-1527, Rev. 2, Numatec Hanford Corporation, Richland, Washington.

Smith, K. E., 1998, Multi-Canister Overpack Design Report, HNF-SD-SNF-DR003, Rev. 1, Duke Engineering and Services Hanford, Richland, Washington. 


\section{DISTRIBUTION SHEET}

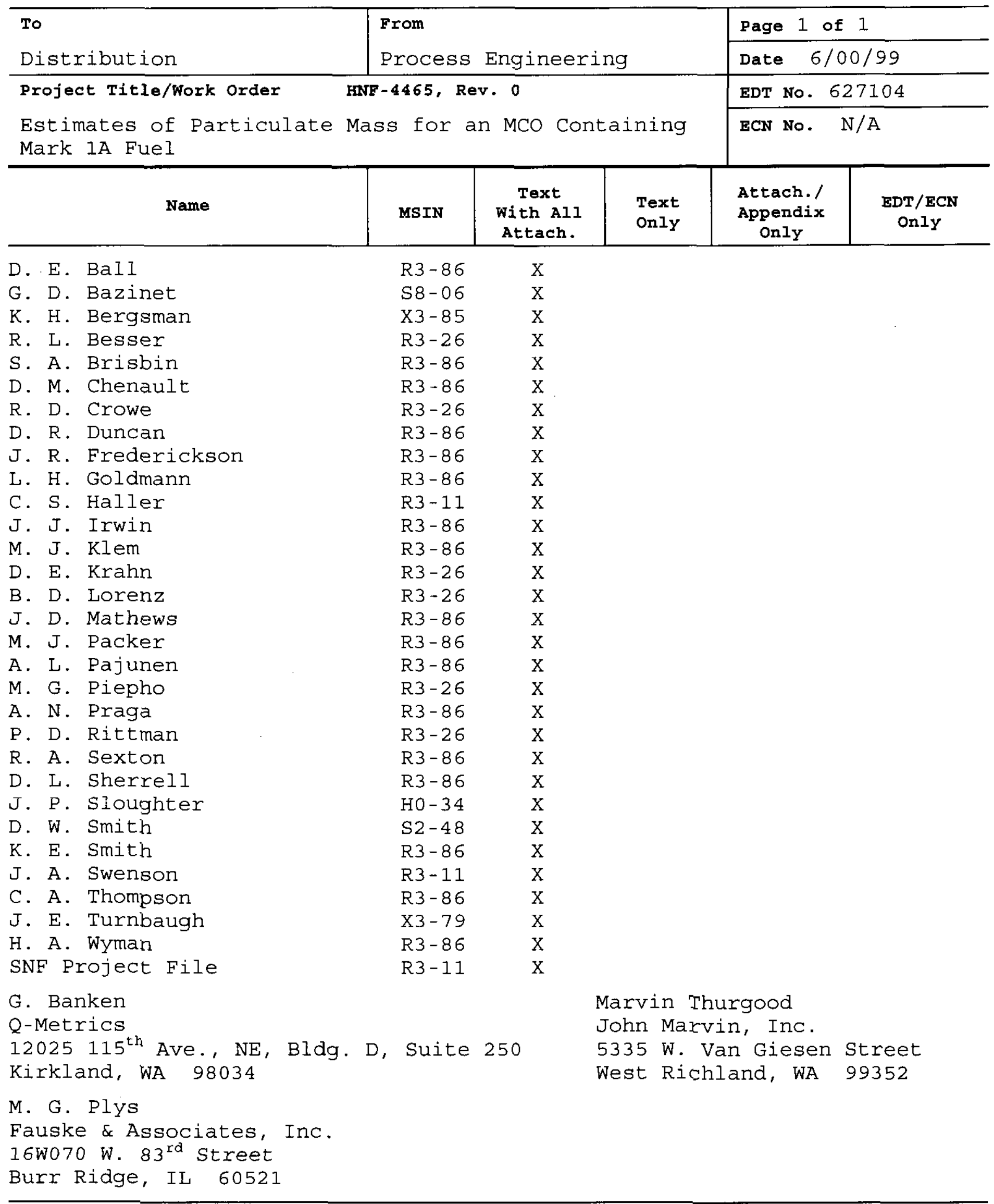

